\title{
Synthesis, Characterization, Thermal Degradation Studies of Transition Metal Complexes of 5-Methoxy-5,6-Bis(3-Nitrophenyl) - 4, 5-Dihydro-1, 2, 4- Triazine - $3(2 H)$ - Thione and Their Biological Activities
}

\author{
T.C.M.Yuvaraj ${ }^{1}$, P. Parameshwara Naik ${ }^{1 *}$, G. Krishnamurthy ${ }^{1}$, T.V.Venkatesh ${ }^{2}$, \\ T. Manjuraj ${ }^{1}$ \\ ${ }^{1}$ Department of Chemistry, Sahyadri Science College (Auto),Shimoga, Karnataka, India \\ ${ }^{2}$ Department of Chemistry, Kuvempu University, Shankaraghatta, Karnataka, India \\ parashchem@gmail.com
}

\begin{abstract}
H)-thione (NBTS) and its Ni(II), $\mathrm{Co}(I I)$ and $\mathrm{Cu}(\mathrm{II})$ metal complexes have been synthesized and their structure elucidated by elemental analysis, conductivity measurements, UV-Visible, FT-IR, ${ }^{1} H$-NMR,LC-Mass and thermal analysis. The complexes are soluble in almost all organic solvents and are non-electrolytes. Thermal analysis are investigated and showed either two or three thermal decomposition steps. Kinetic parameters such as Ea, $\Delta H, \Delta S$ and $\triangle G o f$ the thermal decomposition stages have been evaluated using Broido's method. The antibacterialand antioxidantactivity of the uncoordinated ligand and its metal complexes have been studied.The results indicate that the complexes are more potent when compared to the ligand.
\end{abstract}

Keywords: Thiosemicarbazone, thermal analysis, conductivity measurements, antibacterial and antioxidant activity.

\section{INTRODUCTION}

Template reactions remain at the heart of macrocyclic chemistry and are the best aids for the preparation of macrocyclic complexes. ${ }^{[1-2]}$ Generally transition metal ions have been used as templates. ${ }^{[3]}$ The importanceof macrocyclic complexes in coordination chemistry is because of its various applications in biological processes such as photosynthesis and dioxygen transport, catalyticproperties, potential applications as metal extractants and radiotherapeutic agents. ${ }^{[4]}$ The importance of macrocyclic complexes is due to their resemblance with many natural systems like porphyrins and cobalamines. ${ }^{[5]}$ Some macrocyclic complexes have been reported to have antiinflammatory approach. ${ }^{[6]}$

Schiff's base macroligands derived from thiosemicarbazide and their complexes are of significant interest for their pharmacological properties as antibacterial and anticancer agents. ${ }^{[7-8]}$ one of the most promising areas in which thiosemicarbazone compounds are being developed is their use against cancer. The presence of metal ion increases the activity or contributes to migrate the side effects of the organic parent compounds. ${ }^{[9]}$ Thiosemicarbazones are a unique and versatile type of ligand amongest the sulfur family not only because they possess a variety of flexible donor sets but also due to the fact that they exhibit diverse biological, structural and electrochemical properties. ${ }^{[10]}$ It is well established that their transition metal complexes are more potent antimalerial, antibacterial, antileprotic and antitumor agents than parent thiosemicarbazones ${ }^{[11]}$ Literature survey reveal that many thiosemicarbazones derivatives are known to possess good biological activities like antimicrobial, ${ }^{[12-13]}$ anti-inflammatory, analgesic, diuretic and antiviral activities. Reactions of 5methoxy-5, 6-bis (3-nitrophenyl)-4, 5-dihydro-1, 2, 4-triazine-3(2H)- thione with nickel (II), cobalt (II) and copper (II) chloride yield different complexes depending on the synthetic conditions. ${ }^{[14]}$

In the present paper, we are reporting the template synthesis of thioamidemacrocyclic complexes of copper (II), cobalt (II) and nickel (II) ions. The new complexes are characterizedwith the help of various physicochemical techniques likeIR, ${ }^{1} \mathrm{H}$ NMR, magnetic susceptibilities, elemental analysis, conductance measurementsand the calculated activation kinetic parameters of the decomposition of 
the prepared complexes, show that the thermal stability of metal complexes depends essentially on the nature of both the central metal ion and the ligand.The study includes the structural elucidationof the isolated complexes by conventional techniques, their thermaldegradation kinetics by Broido's model ${ }^{[15]}$ Also, the antioxidantactivity of all complexes using ABTS or DPPH radical scavengingmethods and antibactreial activities havebeen discussed.

\section{MATERIALS AND MethodS}

The chemicals thiosemicarbazide, benzil and methanol were purchased from the Sigma Aldrich, Laboratory chemicals, Bangalore, Karnataka, India. Nickel(II)acetate tetrahydrate, Cobalt(II)chloride tetrahydrate, Copper(II)acetate monohydrate were purchased from MERCK, Sudha Traders, Shimoga, Karnataka, India and were used as received. The solvents were distilled and dried before use by following the reported procedure. ${ }^{[16]}$

\subsection{Physical Measurements}

The elemental analysis (C, H, N, S) was performed using Perkin-Elmer 2400 II CHNS/O Elemental analyzer. Melting point of the ligand and thier metal complexes was measured by using melting point apparatus model code NAMPA/045 and are uncorrected. UV-Visible spectra were measured in DMF on an ocean optics USB 4000USAspectrophotometer, using $1 \mathrm{~cm}$ path length cuvette at room temperature. Infrared spectra were recorded using FT-IR 8400s Shimadzu spectrometer with $\mathrm{KBr}$ pellets in the range of $400-4000 \mathrm{~cm}^{-1}$. The molar conductance data was measured using freshly prepared DMSO solutions $\left(10^{-3} \mathrm{M}\right)$ at $25^{\circ} \mathrm{C}$ with a EQUIP-TRONICS model-660A instrument. The ${ }^{1} \mathrm{H}$ NMR spectra have been recorded as $400 \mathrm{MHz}$ Varian-AS NMR spectrometer in DMSO- $\mathrm{d}_{6}$ using tetramethylsilane (TMS) as theinternal standard.The thermal analysis (DTA and TGA) were carried out on a Shimadzu DT-30 and TG-50 thermal analyzers in therange $27-800^{\circ} \mathrm{C}$ at the heating rate of $10^{0} \mathrm{Cmin}^{-1}$ in nitrogen atmosphere $80.0 \mathrm{~mL} / \mathrm{min}$. The magnetic susceptibilityvalues measured at the room temperature using the Gouy method with mercuric tetrathiocyanatocobaltate (II) as standard. The diamagnetic corrections were made using Pascal's constants (El-Tabl1996). Mass spectra was recorded using theinstrument Code;SC/AD/10-014 .
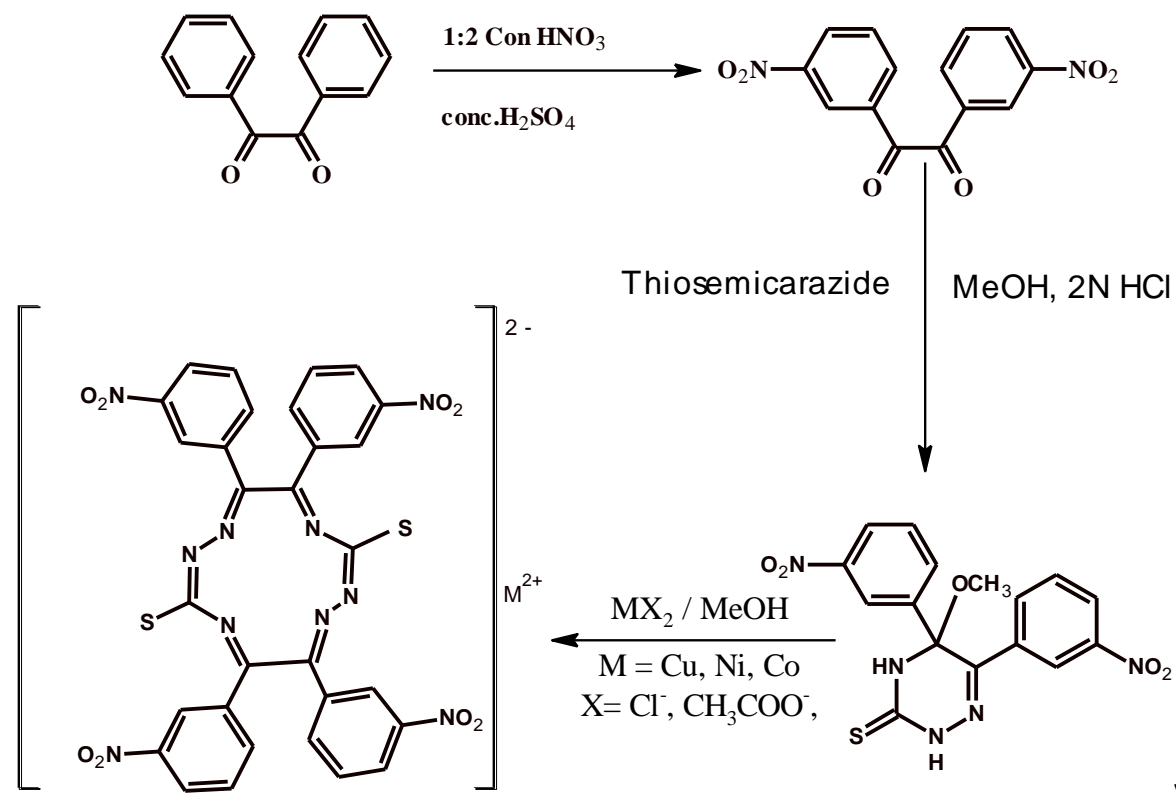

Thiosemicarazide $\mathrm{MeOH}, 2 \mathrm{~N} \mathrm{HCl}$

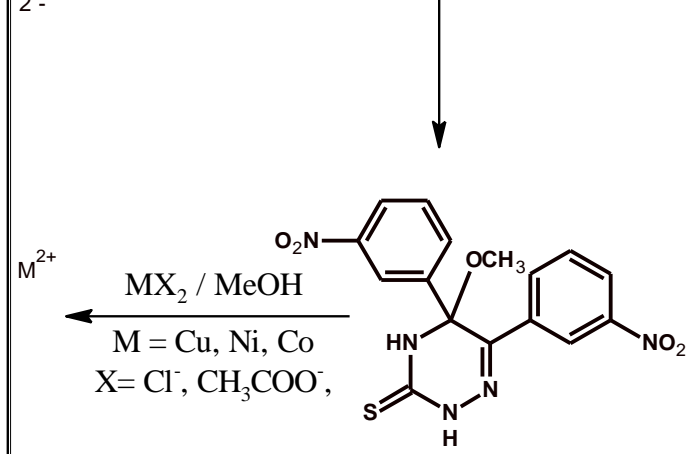

V

Scheme1. Synthesis of 5-methoxy-5,6-bis(3-nitrophenyl)-4,5-dihydro-1,2,4-triazine-3(2H)-thione and its complexes

\subsection{Synthesis of 1,2-Bis(3-Nitrophenyl) Ethane-1,2-Dione}

A solution of benzil $(8.4 \mathrm{~g}, 0.04 \mathrm{~mol})$ dissolved in $10 \mathrm{~mL}$ of conc. $\mathrm{H}_{2} \mathrm{SO}_{4}$ andthe solution containingconc. $\mathrm{HNO}_{3}$ and conc. $\mathrm{H}_{2} \mathrm{SO}_{4}$ in $(1: 2)$ about $20 \mathrm{~mL}$ was added dropwise and slowly with vigorous stirring under freezing mixture bath, after completing the addition of nitrating mixture, stirring was continued for about $12 \mathrm{hrs}$ at $60^{\circ} \mathrm{C}$. After the reaction, solution was poured into crushed ice. The separated solidproduct was filtered and washed with cold water 5-6 times and dried at room temperature. 
Synthesis, Characterization, Thermal Degradation Studies of Transition Metal Complexes of 5-Methoxy5,6-Bis(3-Nitrophenyl) - 4, 5-Dihydro-1, 2, 4- Triazine - 3 (2H) - Thione and Their Biological Activities

2.3. Synthesis of 5-Methoxy-5, 6-Bis (3-nitrophenyl) - 4, 5-Dihydro- 1, 2, 4 - Triazine -3(2H)Thione (NBTS)

A solution of thiosemicarbazide $(2.00 \mathrm{~g}, 0.022 \mathrm{~mol})$ in $50 \mathrm{~mL}$ of methanol and $20 \mathrm{mLof} 4 \mathrm{~N}$ HClto the solution of 1, 2-bis(3-nitrophenyl)ethane-1,2-dione $(6.08 \mathrm{~g}, 0.02 \mathrm{~mol})$ in $75 \mathrm{mLhot}$ methanolwas added slowlydrop wise with vigarous stirring. After the addition of thereactants, the reaction mixture was stirred upto12hrs at about $45^{\circ} \mathbf{C}$. The reaction was monitored by TLC by using silica gel-G coated plates and using methanol and chloroformin the ratio (0.1:0.9) as an eluent.The reaction mixture on standing overnight anivory coloured solid speratedout, which was filtered off.The precipitate was washed with coldsolution of water and methanol in the ratio $(9: 1)$. The solid so obtained, thenrecrystalised from the ethanol and dried in vacuo.Yield: 88\%; IR $\left(\mathrm{KBr}, \mathrm{cm}^{-1}\right): 3069(\mathrm{~N}-\mathrm{H}), 1556$ $(\mathrm{C}=\mathrm{N}), 1071(\mathrm{~N}-\mathrm{N}), 1218,808(\mathrm{C}=\mathrm{S}), 1527$ (thioamideI),851 (thioamideII), 2955(Ar C-H), $1442(\mathrm{Ar}$ $\mathrm{C}=\mathrm{C}), 1349$ (C-C), $1260(\mathrm{C}-\mathrm{O}), 1349\left(\mathrm{NO}_{2}\right) .{ }^{1} \mathrm{HNMR}\left(\mathrm{DMSO}_{6}, \mathrm{~d}_{6}, 400 \mathrm{MHz}\right): 10.36(1 \mathrm{H}, \mathrm{s}, \mathrm{NH}), 12.56$ $(1 \mathrm{H}, \mathrm{s}, \mathrm{NH}), \quad 7.59-7.22(2 \mathrm{H}, \mathrm{m}, \mathrm{Ar}-\mathrm{H}), 7.92-7.61(2 \mathrm{H}, \mathrm{d}, \mathrm{Ar}-\mathrm{H}), \quad 8.15-8.08(2 \mathrm{H}, \mathrm{d}, \mathrm{Ar}-\mathrm{H}), \quad 8.36-8.30($ $2 \mathrm{H}, \mathrm{d}, \mathrm{Ar}-\mathrm{H})$ and $3.32\left(3 \mathrm{H}, \mathrm{s}, \mathrm{OCH}_{3}\right)$. Mass Spectra $\left(\mathrm{M}^{+}\right)$at m/z 388, $356\left(\mathrm{M}^{-} \mathrm{OCH}_{3}\right)$

\subsection{Synthesis of Metal Complexes}

A solution of nickel(II) chloridehexa hydrate $(0.474 \mathrm{~g}, 0.002 \mathrm{~mol})$, cobalt(II)chloride hexahydrate $(0.474 \mathrm{~g}, 0.002 \mathrm{~mol})$ and copper(II)chloride dihydrate $(0.340 \mathrm{~g}, 0.002 \mathrm{~mol})$ in $10 \mathrm{mLmethanol}$ was added to a solution of 5-methoxy-5,6-bis(3-nitrophenyl)-4,5-dihydro-1,2,4-triazine-3( $2 H$ )-thione $(1.548 \mathrm{~g}, 0.004 \mathrm{~mol})$ in $20 \mathrm{~mL}$ methanol to obtain corresponding metal complexes. The resulting reaction mixture was reflux with stirred for 6hrs. The coloured solid formed was filtered and washedwith the solutionof cold water and methanol in the ratio $(1: 1)$. The solid obtained was dried in vacuo. ${ }^{[17]}$

[Ni (NBTS) ] $_{2} \mathbf{C l}_{\mathbf{2}}$ complex; Yield: 78\%.;IR $\left(\mathrm{KBr}, \mathrm{cm}^{-1}\right)$ : 3047(Ar-H), $1344(\mathrm{C}-\mathrm{N}), 121$

(C-S), 1555 (Ar C-C), $1517\left(\mathrm{NO}_{2}\right), 1045$ (N-N), 468 (Ni-S)

[Co (NBTS) $)_{2}$ ]Cl $\mathbf{2}_{2}$ complex; Yield: 68\%.IR $\left(\mathrm{KBr}, \mathrm{cm}^{-1}\right): 3056(\mathrm{Ar}-\mathrm{H}), 1344.88(\mathrm{C}-\mathrm{N})$,

1215(C-S), 1557(Ar C-C), $1519\left(\mathrm{NO}_{2}\right), 1047$ (N-N), 417(Co-S)

[Cu (NBTS) $)_{2}$ ] $\mathbf{C l}_{2}$ complex; Yield: 81\%; IR (KBr, cm $\left.{ }^{-1}\right): 3076(\mathrm{Ar}-\mathrm{H}), 1349(\mathrm{C}-\mathrm{N}), 1184$

(C-S), 1524 (Ar C-C), $1499\left(\mathrm{NO}_{2}\right), 1095(\mathrm{~N}-\mathrm{N}), 417$ (Cu-S)

\section{RESUlts AND DisCUSSION}

The colours, elemental analysis, stoichiometries of ligand and its complexes are presented in Table 1. Elemental analysis data are consistent with 1:2 ratio of ligand and metal ion. The metal chelates derived from 1,2-bis(3-nitrophenyl)ethane-1,2-dione and thiosemicarbazide may be represented formula: $\left[\mathrm{M}\left(\mathrm{C}_{30} \mathrm{H}_{16} \mathrm{~N}_{10} \mathrm{O}_{8} \mathrm{~S}_{2}\right)\right] \mathrm{X}_{2}$ where $\mathrm{M}=\mathrm{Cu}(\mathrm{II}), \mathrm{Co}(\mathrm{II}), \mathrm{Ni}(\mathrm{II})$ and $\mathrm{X}=\mathrm{Cl}^{-1}, \mathrm{CH}_{3} \mathrm{COO}^{-1}$. The measurements of molarconductance show that thesechelates are 1:2electrolytes. The ${ }^{1} \mathrm{HNMR}$ signals at $10.36,12.56$ and 3.32ppm are assigned to $-\mathrm{NH}$ and $-\mathrm{OCH}_{3}$ protons respectively. The aromatic protons show doublet and multiplet at 7.92-7.61, 8.15-8.08, 8.36-8.30 and 7.59-7.22 ppm range.The NMRspectra of ligand wasshowed in Fig.1.Mass spectra data confirm the structure of ligand and complexes as indicated by molecular ion peak $\left(\mathrm{M}^{+1}\right)$ corresponding to their molecular weight.The Massspectrum of uncoordinated ligand with its metal complexes were presented in Fig.2 and Fig.3.

Table1. Physical and analytical data of the ligand (NBTS) and its metal complexes

\begin{tabular}{|c|c|c|c|c|c|c|c|c|c|}
\hline \multirow[t]{2}{*}{ Empirical Formula } & \multicolumn{5}{|c|}{$\begin{array}{l}\text { \% chemical analysis: Found } \\
\text { (Calculated) }\end{array}$} & \multirow{2}{*}{$\begin{array}{c}\Omega M \text { in } \\
\mathrm{DMSO}^{-1} \\
\left(\mathrm{ohm}^{-1}\right. \\
\mathrm{cm}^{2} \\
\left.\mathrm{~mol}^{-1}\right)\end{array}$} & \multirow{2}{*}{$\begin{array}{c}\text { M.P } \\
\text { in }\left({ }^{\circ} \mathrm{C}\right) \\
\text { Colour }\end{array}$} & \multirow[t]{2}{*}{$\begin{array}{c}\mu_{\text {eff }} \\
\text { (B. M.) }\end{array}$} & \multirow{2}{*}{$\begin{array}{l}\text { Mol. } \\
\text { Wt. } \\
\text { Found } \\
\text { (Calcd) }\end{array}$} \\
\hline & $\mathbf{C}$ & $\mathbf{H}$ & $\mathbf{N}$ & $\mathbf{S}$ & Metal & & & & \\
\hline $\mathrm{C}_{16} \mathrm{H}_{13} \mathrm{~N}_{5} \mathrm{O}_{5} \mathrm{~S}$ & $\begin{array}{c}49.61 \\
(49.22)\end{array}$ & $\begin{array}{c}3.34 \\
(3.38)\end{array}$ & $\begin{array}{c}18.29 \\
(18.08)\end{array}$ & $\begin{array}{c}8.28 \\
(8.18)\end{array}$ & --- & --- & $\begin{array}{l}\text { 186-188 } \\
\text { Ivory }\end{array}$ & --- & $\begin{array}{c}388 \\
(387.37)\end{array}$ \\
\hline$\left[\mathrm{Cu}\left(\mathrm{C}_{30} \mathrm{H}_{16} \mathrm{~N}_{10} \mathrm{O}_{8} \mathrm{~S}_{2}\right)\right] \mathrm{Cl}_{2}$ & $\begin{array}{c}43.24 \\
(42.74)\end{array}$ & $\begin{array}{c}1.99 \\
(1.91)\end{array}$ & $\begin{array}{c}16.61 \\
(16.87)\end{array}$ & $\begin{array}{c}7.71 \\
(7.61)\end{array}$ & $(7.54)$ & 62.4 & $\begin{array}{l}220-223 \\
\text { maroon }\end{array}$ & 2.56 & $\begin{array}{c}845.70 \\
(843.18)\end{array}$ \\
\hline
\end{tabular}


P. Parameshwara Naik et al.

\begin{tabular}{|c|c|c|c|c|c|c|c|c|c|}
\hline \hline $\left.\mathrm{Co}\left(\mathrm{C}_{30} \mathrm{H}_{16} \mathrm{~N}_{10} \mathrm{O}_{8} \mathrm{~S}_{2}\right)\right] \mathrm{Cl}_{2}$ & $\begin{array}{c}42.99 \\
(42.97)\end{array}$ & $\begin{array}{c}1.97 \\
(1.92)\end{array}$ & $\begin{array}{c}16.95 \\
(16.70)\end{array}$ & $\begin{array}{c}7.75 \\
(7.65)\end{array}$ & $\begin{array}{c}--- \\
(7.03)\end{array}$ & 81.3 & $\begin{array}{c}192-193 \\
\text { Gray }\end{array}$ & 3.53 & $\begin{array}{c}838.91 \\
(838.33)\end{array}$ \\
\hline$\left[\mathrm{Ni}\left(\mathrm{C}_{30} \mathrm{H}_{16} \mathrm{~N}_{10} \mathrm{O}_{8} \mathrm{~S}_{2}\right)\right] \mathrm{Cl}_{2}$ & $\begin{array}{c}43.03 \\
(42.99)\end{array}$ & $\begin{array}{c}1.98 \\
(1.92)\end{array}$ & $\begin{array}{c}16.85 \\
(16.71)\end{array}$ & $\begin{array}{c}7.95 \\
(7.65)\end{array}$ & $\begin{array}{c}--- \\
(7.00)\end{array}$ & 71.4 & $\begin{array}{c}206-208 \\
\text { Olive }\end{array}$ & Diamagnetic & $\begin{array}{c}838.91 \\
(838.13)\end{array}$ \\
\hline
\end{tabular}

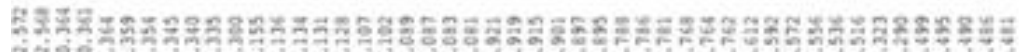

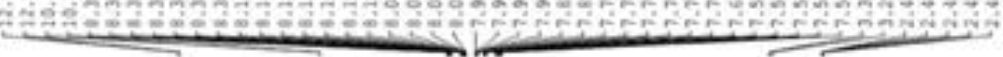
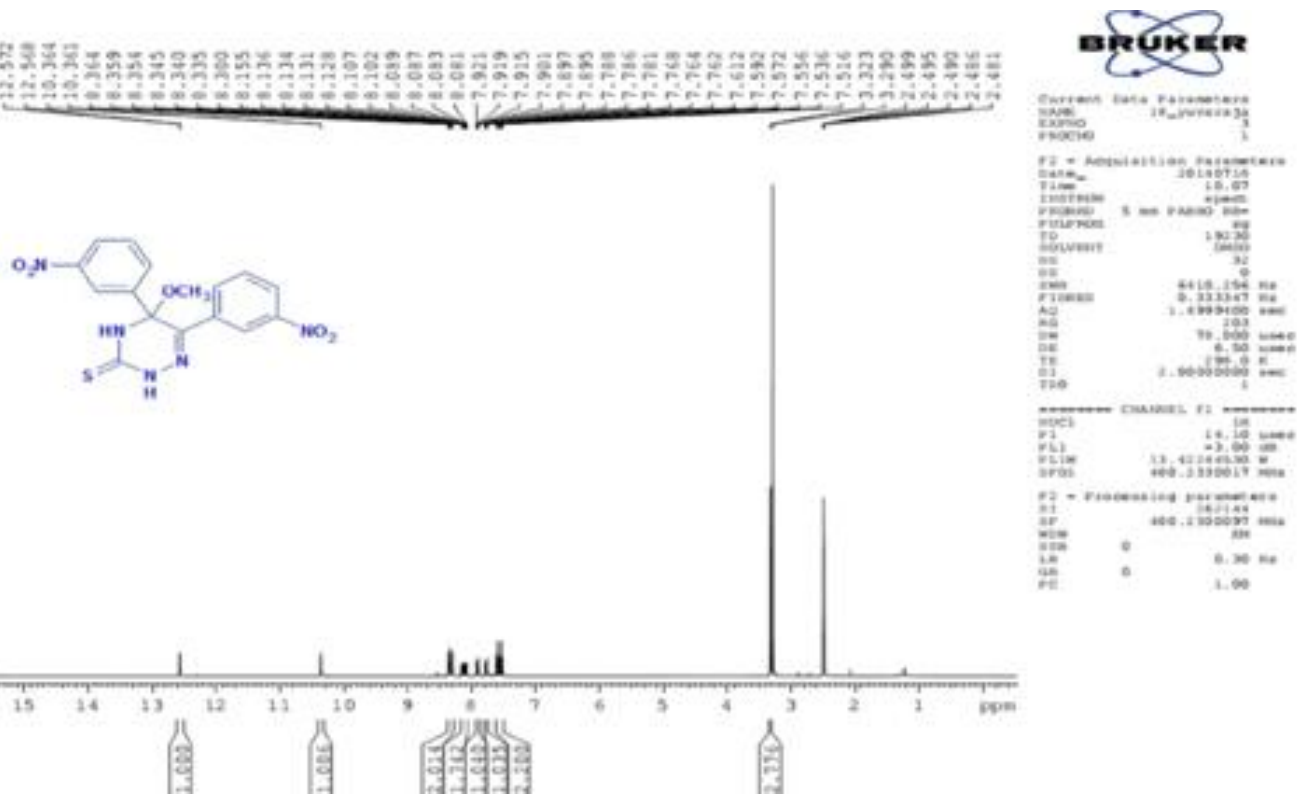

Fig1. ${ }^{l} H N M R$ Spectra of NBTS

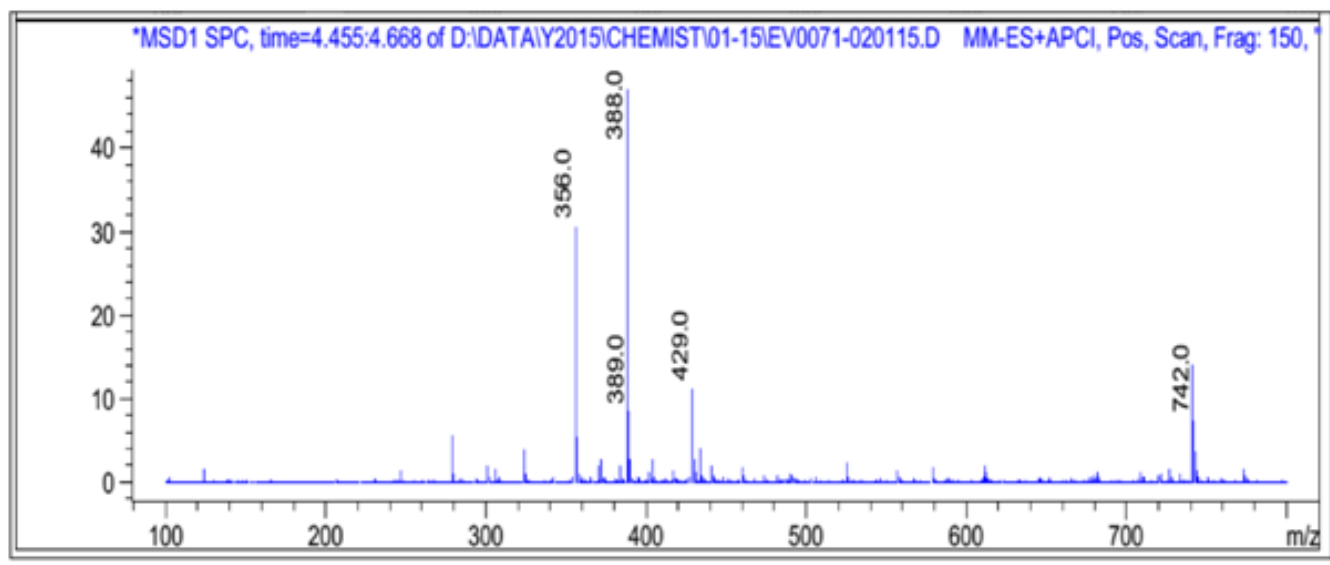

Fig2. LC - Mass Spectra of NBTS

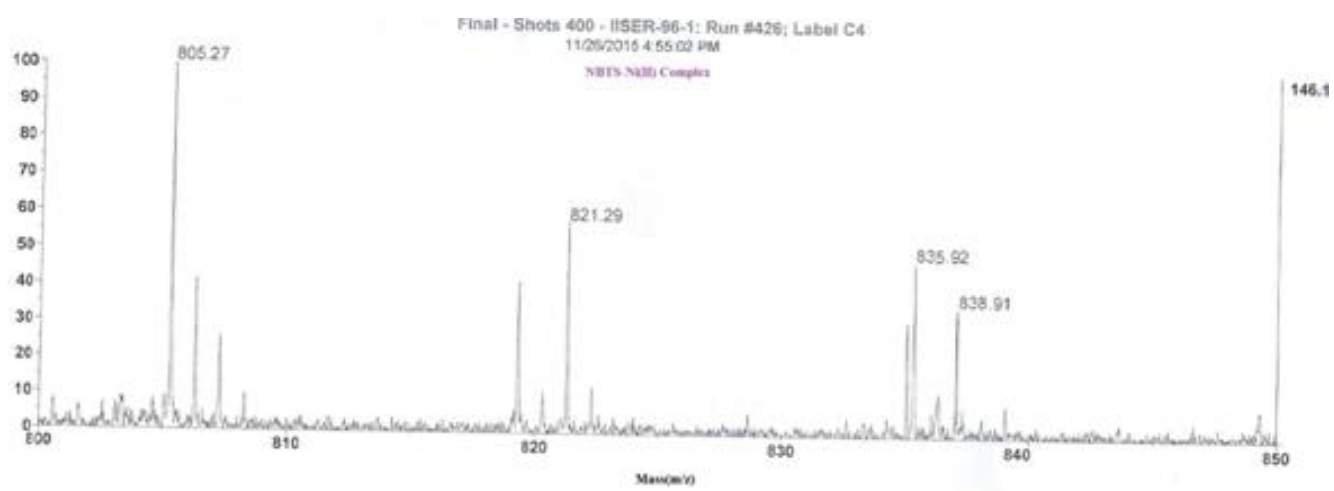

Fig3. Maldi Mass Spectra of $\left[\mathrm{Ni}(\mathrm{NBTS})_{2}\right] \mathrm{Cl}_{2}$

\subsection{FT-IR Spectral Studies}

The IR spectrum of the ligand showed a strong absorption band at $1671 \mathrm{~cm}^{-1}$ which was assigned to the azomethene group $(\mathrm{C}=\mathrm{N}),{ }^{[18-19]}$ the strong band observed at $1527 \mathrm{~cm}^{-1}$ and $732 \mathrm{~cm}^{-1}$ in the spectrum 
Synthesis, Characterization, Thermal Degradation Studies of Transition Metal Complexes of 5-Methoxy5,6-Bis(3-Nitrophenyl) - 4, 5-Dihydro-1, 2, 4- Triazine - 3 (2H) - Thione and Their Biological Activities

was due to the $(\mathrm{C}=\mathrm{S}) .{ }^{[20-22]}$ The bands observed at $3069 \mathrm{~cm}^{-1}$ and $3047 \mathrm{~cm}^{-1}$ were assigned to $(\mathrm{N}-\mathrm{H})$ and $(\mathrm{Ar}-\mathrm{H})$ vibrations respectively. This indicates that the ligand present in thione form. The comparison of IR spectrum of uncoordinated ligand with its metal complexes were presented in Fig.4.The spectrum indicate that the presence due tothe azomethene moiety $\mathrm{C}=\mathrm{N}$ was shifted to lower frequencyas compared to the uncoordinated ligand, ${ }^{[23]}$ indicatingthatcoordination of ligand with metal ion. In addition $\mathrm{C}=\mathrm{Sstretching}$ frequency observedat $1256 \mathrm{~cm}^{-1}$ in ligand was shifted in the spectra of the complexes, showed the sulphur in the coordination with metal ion. The appearance of new band at $440 \mathrm{~cm}^{-1}$ in the spectrum of the complexes also support it, ${ }^{[24-25]}$ which were assignable to (M-S) vibration, respectively in nickel, copper and cobalt complexes. ${ }^{[26]}$

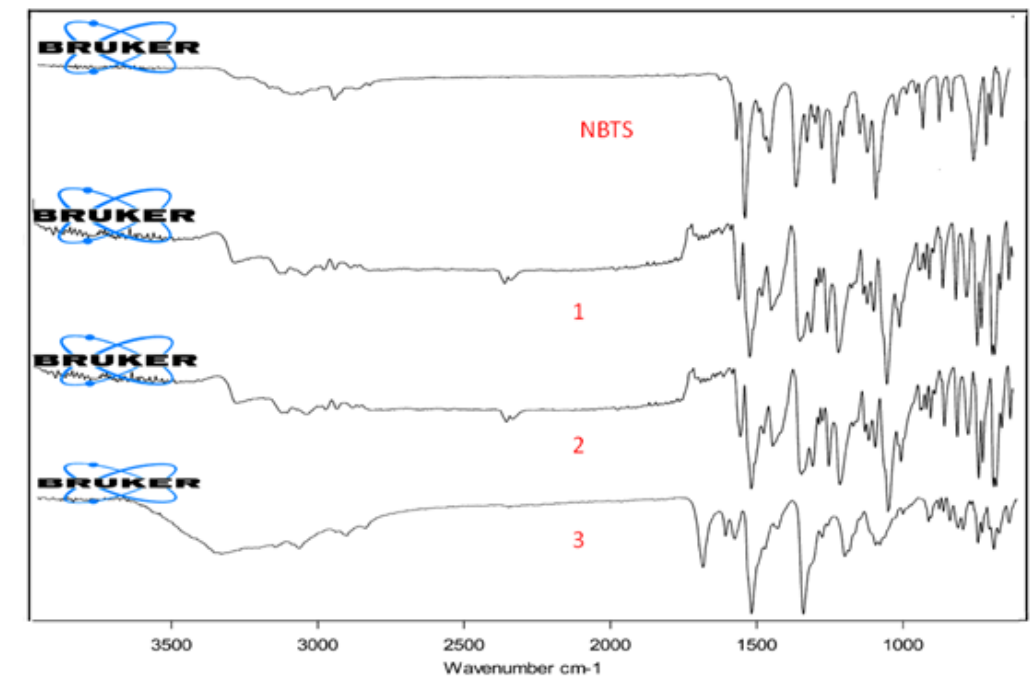

Fig4. IR Spectra of NBTS and metal complexes

\subsection{Molar Conductance}

It is observed that the molar conductance values of the complexes are in the range of $62-81 \mathrm{ohm}^{-1} \mathrm{~cm}^{2}$ $\mathrm{mol}^{-1}$. The values indicate that these complexes behave as uni-bivalent electrolytes. The tests for anions are positive before decomposing and decomposing the chelates showing their presence outside of coordination sphere. ${ }^{[27]}$

\subsection{Electronic Absorption Spectra}

The observed electronictransitions found to agree with the expected transitions for octahedral geometry conclusions arrived from magnetic susceptibility measurements. ${ }^{[28-29]}$ The solid state [Co(NBTS $\left.)_{2}\right] \mathrm{Cl}_{2}$ complex showed the band at $14,705 \mathrm{~cm}^{-1}$ which can be ascribed into ${ }^{4} \mathrm{~T}_{1} \mathrm{~g}(\mathrm{~F}) \rightarrow$ ${ }^{4} \mathrm{~T}_{2} \mathrm{~g}(\mathrm{~F})\left[\mathrm{v}_{1}\right],{ }^{4} \mathrm{~T}_{1} \mathrm{~g}(\mathrm{~F}) \rightarrow{ }^{4} \mathrm{~A}_{2} \mathrm{~g}(\mathrm{~F})\left[\mathrm{v}_{2}\right]$ and ${ }^{4} \mathrm{~T}_{1} \mathrm{~g}(\mathrm{~F}) \rightarrow{ }^{4} \mathrm{~T}_{1} \mathrm{~g}(\mathrm{P})\left[\mathrm{v}_{3}\right]$. The electronic spectrum of $\mathrm{Co}(\mathrm{II})$ are two bands at $14,705 \mathrm{~cm}^{-1}$ and $22,321 \mathrm{~cm}^{-1}$ due to ${ }^{4} \mathrm{~T}_{1} \mathrm{~g}(\mathrm{~F}) \rightarrow{ }^{4} \mathrm{~T}_{2} \mathrm{~g}(\mathrm{~F})$ and ${ }^{4} \mathrm{~T}_{1} \mathrm{~g}(\mathrm{~F}) \rightarrow{ }^{4} \mathrm{~T}_{1} \mathrm{~g}(\mathrm{P})$ transitions corresponding to octahedral geometry. The Gray colour of cobalt (II) complex is also suggestive of octahedral geometry. ${ }^{[30-31]}$ The $\left[\mathrm{Ni}(\mathrm{NBTS})_{2}\right] \mathrm{Cl}_{2}$ complex exhibit two transitions in the electronic spectra at about $24,390 \mathrm{~cm}^{-1}$ and $17,857 \mathrm{~cm}^{-1}$ due to ${ }^{3} \mathrm{~A}_{2} \mathrm{~g}(\mathrm{~F}) \rightarrow{ }^{3} \mathrm{~T}_{1} \mathrm{~g}(\mathrm{~F})\left[\mathrm{v}_{1}\right]$ and ${ }^{3} \mathrm{~A}_{2} \mathrm{~g}(\mathrm{~F}) \rightarrow$ ${ }^{3} \mathrm{~T}_{2} \mathrm{~g}(\mathrm{~F})\left[\mathrm{v}_{2}\right]$ transitions respectively are due to octahedral geometry of the complex. ${ }^{[32]}$ The well separated bands indicate that the cobalt(II) have an octahedralgeometry. The broad band at $15,355 \mathrm{~cm}^{-}$ ${ }^{1}$ and a shoulder at23, $809 \mathrm{~cm}^{-1}$ indicative of distorted octahedral geometry for $\left[\mathrm{Cu}(\mathrm{NBTS})_{2}\right]$ $\mathrm{Cl}_{2}$ complex. The comparison of solid UV- spectrum of ligand with its metal complexes were presented in Fig.5.

\subsection{Thermal Analysis Studies of Metal Complexes}

The synthesised complexes were subjected to thermal analysis. The mass loss consideration during the decomposition used to evaluate the kinetic parameters such as $\mathrm{E}_{\mathrm{a}}{ }^{*}, \Delta \mathrm{H}^{*}, \Delta \mathrm{G}^{*}$ and $\Delta \mathrm{S}^{*}$. The nature of decomposition curve indicate that the complexes have been converted to corresponding metal oxides. The weight loss curves and the corresponding differential thermo gravimetric curves for the complex are shown in fig.5.The thermal behavior of cobalt(II), nickel(II) and copper(II) complexes hasbeen studied as a function of temperature. ${ }^{[33]}$ The thermaldecomposition of $\left[\mathrm{Cu}(\mathrm{NBTS})_{2}\right] \mathrm{Cl}_{2}$ complex has occurred in three steps asindicated by DTG curves around 196, 260 and 
$385^{\circ} \mathrm{Ccorresponding} \mathrm{to} \mathrm{the} \mathrm{loss} \mathrm{of} \mathrm{two} \mathrm{coordinated} \mathrm{chloride} \mathrm{ions,} \mathrm{loss} \mathrm{of} \mathrm{four} \mathrm{nitro} \mathrm{group} \mathrm{and} \mathrm{macro}$ cyclic ligand respectively. ${ }^{[34]}$ In the case of $\left[\mathrm{Ni}(\mathrm{NBTS})_{2}\right] \mathrm{Cl}_{2}$ and $\left[\mathrm{Co}(\mathrm{NBTS})_{2}\right] \mathrm{Cl}_{2}$ complexes, decomposition corresponding to the loss of two coordinated chloride ions in the first step 196$200^{\circ} \mathrm{C}$,loss of four nitro group around $260-390^{\circ} \mathrm{C}$ in the second step and greater loss in weight of macro cycliclig and in the range $385-440^{\circ} \mathrm{C}$ in the third step. ${ }^{[35]}$ Finally, the mass decomposes gradually with the formation of metal oxide above $720^{\circ} \mathrm{C}$. The nature of proposed chemical change with the temperature range and the percentage of metaloxide obtained are given in Table 2.TheTGA curves of metal complex were showed in Fig.6.

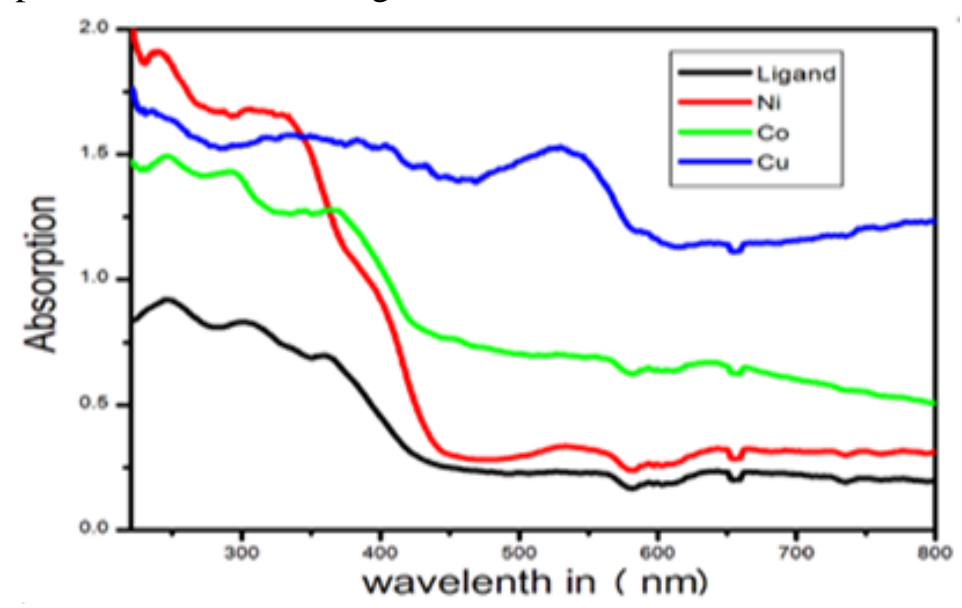

Fig5. Electronic spectra of metal complexes

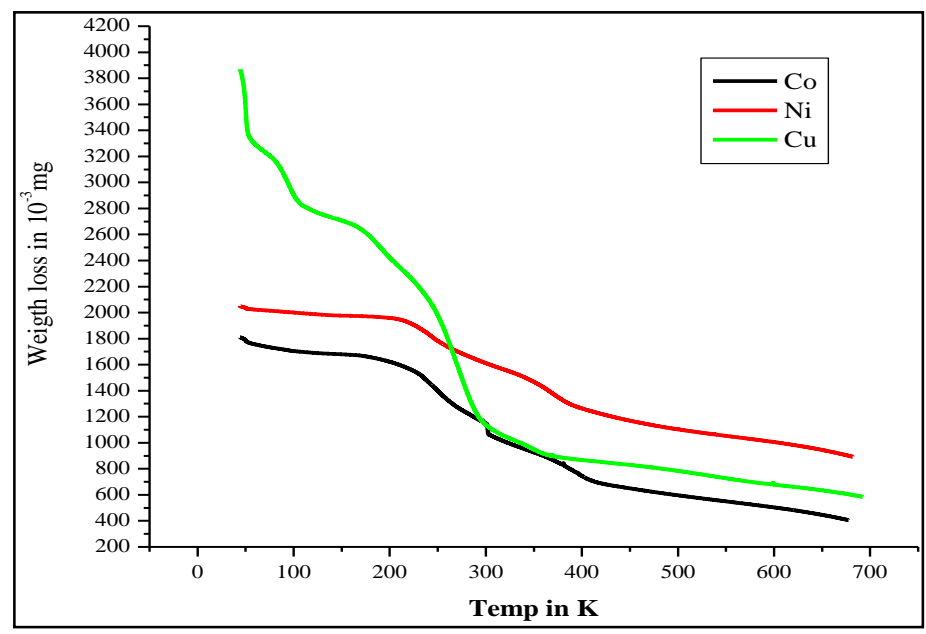

Fig6. TGA Thermogram of metal complexes

Table2. TGA analysis data of the NBTS Complexes with copper (II), cobalt (II) and nickel (II)

\begin{tabular}{|c|c|c|c|c|c|c|c|c|c|}
\hline Complex & $\begin{array}{l}\text { First step } \\
\text { Loss of two } \\
\text { chloride } \\
\text { ion }\end{array}$ & $\begin{array}{l}\text { Mass loss } \\
\text { \%Found } \\
\text { (Cal) }\end{array}$ & $\begin{array}{c}\text { Second } \\
\text { step } \\
\text { loss of } \\
\text { four } \\
\text { nitro } \\
\text { group }\end{array}$ & $\begin{array}{c}\text { Mass } \\
\text { loss } \\
\% \\
\text { Found } \\
\text { (Cal) }\end{array}$ & $\begin{array}{l}\text { Third step } \\
\text { Loss of one } \\
\text { Macrocyclic } \\
\text { Compound }\end{array}$ & $\begin{array}{c}\text { Mass } \\
\text { loss } \\
\% \\
\text { Found } \\
\text { (Cal) }\end{array}$ & Residue & $\begin{array}{c}\text { Temp. } \\
\text { in0C }\end{array}$ & $\begin{array}{c}\% \\
\text { found } \\
\text { (Cal) }\end{array}$ \\
\hline$\left[\mathrm{Cu}(\mathrm{NBTS})_{2}\right] \mathrm{Cl}_{2}$ & $196^{\circ} \mathbf{C}$ & \begin{tabular}{|l|}
8.42 \\
$(9.21)$
\end{tabular} & $260^{\circ} \mathrm{C}$ & $\begin{array}{l}26.56 \\
(26.12)\end{array}$ & $385^{\circ} \mathrm{C}$ & $\begin{array}{l}55.5 \\
(54.82)\end{array}$ & $\mathrm{CuO}$ & 700 & $\begin{array}{l}9.43 \\
(9.12)\end{array}$ \\
\hline$\left[\mathrm{Co}(\mathrm{NBTS})_{2}\right] \mathrm{Cl}_{2}$ & $199^{\circ} \mathbf{C}$ & \begin{tabular}{|l|}
8.46 \\
$(8.33)$
\end{tabular} & $340^{\circ} \mathbf{C}$ & $\begin{array}{l}26.72 \\
(27,67)\end{array}$ & $600^{\circ} \mathrm{C}$ & $\begin{array}{l}55.75 \\
(56.48)\end{array}$ & $\mathrm{CoO}$ & 720 & $\begin{array}{l}8.94 \\
(9.40)\end{array}$ \\
\hline$\left[\mathrm{Ni}(\mathrm{NBTS})_{2}\right] \mathrm{Cl}_{2}$ & $200^{\circ} \mathbf{C}$ & $\begin{array}{l}8.47 \\
(8,82)\end{array}$ & $390^{\circ} \mathbf{C}$ & $\begin{array}{l}26,72 \\
(26.56)\end{array}$ & $440^{\circ} \mathbf{C}$ & $\begin{array}{l}55.55 \\
(5612)\end{array}$ & $\mathrm{NiO}$ & 710 & $\begin{array}{l}8.90 \\
(8.33)\end{array}$ \\
\hline
\end{tabular}

The kinetic and thermodynamic activation parameters of decomposition processes of dehydrated complexes, namely activation energy $\left(\mathrm{E}_{\mathrm{a}}^{*}\right)$, enthalpy $\left(\Delta \mathrm{H}^{*}\right)$, entropy $\left(\Delta \mathrm{S}^{*}\right)$, and Gibbs free energy change of the decomposition $\left(\Delta \mathrm{G}^{*}\right)$, were evaluated graphically by employing the Broido's relation: $\ln [\ln (1 / \mathrm{y})]=\mathrm{E}_{\mathrm{a}}^{*} / \mathrm{RT}_{\mathrm{d}}-\ln \mathrm{A}-\ln \left(8.314 / \mathrm{T}_{\mathrm{d}}\right)$ 
Synthesis, Characterization, Thermal Degradation Studies of Transition Metal Complexes of 5-Methoxy5,6-Bis(3-Nitrophenyl) - 4, 5-Dihydro-1, 2, 4- Triazine - 3 (2H) - Thione and Their Biological Activities

Where $T_{d}$ is the decomposition temperature, $R$ is the gas constant and $E_{a}^{*}$ is the activation energy in $\mathrm{kJ} \cdot \mathrm{mol}^{-1}$.A plot of the left-hand side of equation (1) against $1 / \mathrm{T}$ gave a slope from which $\mathrm{E}_{\mathrm{a}}^{*}$ was calculated and A (Arrhenius factor) was determined from the intercept. The entropy of activation $\left(\Delta \mathrm{S}^{*}\right)$, enthalpy of activation $\left(\Delta \mathrm{H}^{*}\right)$ and the free energy change of activation $\left(\Delta \mathrm{G}^{*}\right)$ were calculated using the following Eyring equations:

$\Delta \mathrm{S}^{*}=2.303[\log (\mathrm{Ah} / \mathrm{kT})] \mathrm{R}$

$\Delta \mathrm{H}^{*}=\mathrm{E}_{\mathrm{a}}{ }^{*}-\mathrm{RT}$

$\Delta \mathrm{G}^{*}=\Delta \mathrm{H}^{*}-\mathrm{T} \Delta \mathrm{S}^{*}$

The data are summarized in Table 3. The activation energies of decomposition were in the range 1.79 - $5.23 \mathrm{~kJ} \mathrm{~mol}^{-1}$. The high values of the activation energies reflect the thermal stability of the complexes. ${ }^{[36]}$ The positive sign of $\mathrm{DG}^{*}$ for the investigated complexesindicates that the free energy of the final residue is higherthan that of the initial compound and all the decomposition stepsare nonspontaneous processes.Also, the negative values of $\mathrm{DS}^{*}$ and $\mathrm{DH}^{*}$ are owing to the increase of the order as a result of solvation process and the chelation proceses is exothermic and it is favorable at lower temperatures. ${ }^{[37-38]}$ The entropy of activation had negative values in all the complexes, which indicates that the decomposition reactions proceed with a lower rate than the normal ones. Table3. Kinetic and Thermodynamic parameters of NBTS complexes

\begin{tabular}{|c|c|c|c|c|c|c|c|}
\hline $\begin{array}{c}\text { Metal } \\
\text { Complex }\end{array}$ & $\begin{array}{c}\text { Decomposition } \\
\text { Temperature } \\
\left({ }^{0} \mathrm{C}\right) \\
\end{array}$ & $\begin{array}{c}\text { DTA }_{\max } \\
\left({ }^{0} \mathrm{C}\right)\end{array}$ & \begin{tabular}{|c|} 
Activation \\
Energy E E $_{\mathrm{a}}^{*}$ \\
$\mathrm{KJ} / \mathrm{mole}^{2}$ \\
\end{tabular} & $\begin{array}{c}\text { Frequency } \\
\text { Factor } \\
\text { In A Min }{ }^{-1} \\
\end{array}$ & $\begin{array}{c}\Delta \mathbf{H}^{*} \\
\mathbf{K J} / \text { mole }\end{array}$ & $\begin{array}{c}\Delta \mathbf{S}^{*} \\
\mathrm{~J} / \mathrm{mole}\end{array}$ & $\begin{array}{c}\Delta \mathbf{G}^{*} \\
\mathbf{K J} / \mathbf{m o l e}\end{array}$ \\
\hline & $180-500$ & & & 17.6140 & & -152 & 51.8882 \\
\hline $\mathrm{Co}(\mathrm{NB}$ & 22 & 400 & 7927 & 3.5670 & -1.5328 & -150.67 & 60.2584 \\
\hline$\left[\mathrm{Ni}(\mathrm{NBTS})_{2}\right] \mathrm{Cl}_{2}$ & $240-500$ & 370 & 3.6609 & 3.4723 & 5.8475 & -151.77 & 56.1607 \\
\hline
\end{tabular}

\section{IN Vitro - ANTIOXIDANTS STUDIES}

\subsection{DPPH Free Radical Scavenging Activity}

1,1-Diphenyl-2-picrylhydrazyl (DPPH) is a stablefree radical which has maximum optical absorbance at $517 \mathrm{~nm} \cdot{ }^{[39]}$ The radical scavenging ability of synthesized compoundsand the ascorbic acid (standard) was tested on the basis of the radical scavenging effect on DPPH free radical. ${ }^{[40-41]}$ Different concentration of compounds and standard namely $25,50,100,200$, and $250 \mu \mathrm{g} / \mathrm{mL}$ were prepared in methanol. In clean and labeled test tubes, $2 \mathrm{mLof}$ DPPH solution $(0.002 \%$ in methanol $)$ was mixed with 2 mLof different concentration of compounds and standard separately. The tubes were incubated at room temperature in dark for $30 \mathrm{~min}$. and the optical density was measured at $517 \mathrm{~nm}$ using UVVisible Spectrophotometer. ${ }^{[42-43]}$ The absorbance of the DPPH control was also noted. The scavenging activity was calculated using the formula:

Scavenging activity $(\%)=\left[\left(\mathrm{A}_{\mathrm{DPPH}} \mathrm{A}_{\mathrm{TEST}}\right) / \mathrm{A}_{\mathrm{DPPH}}\right] \times 100$

Where $A_{D P P H}$ is the absorbance of DPPH without test sample (control) and $\mathrm{A}_{\text {TEST }}$ is the absorbance of DPPH in thepresence of test sample.

Antioxidant activity of different concentration of complexes in methanol and ascorbic acid in terms of free radical scavenging ability was evaluated using DPPH free radical assay. The compounds exhibited marked antioxidant activity by scavenging DPPH* (free radical) and converting into DPPH and the activity was found to be dose dependent. The complex $\left[\mathrm{Cu}(\mathrm{NBTS})_{2}\right] \mathrm{Cl}_{2}$ was showed more potent followed by other complexes. The result was tabulated in Table 4.

Table4. DPPH Free Radical Scavenging Activity of NBTS and its metal complexes

\begin{tabular}{|c|c|c|c|c|c|}
\hline \multirow{2}{*}{ Compound } & \multicolumn{5}{|c|}{ Scavenging activity of different concentrations $(\boldsymbol{\mu g} / \mathbf{m L})$ in \% } \\
\cline { 2 - 6 } & $\mathbf{2 5}$ & $\mathbf{5 0}$ & $\mathbf{1 0 0}$ & $\mathbf{2 0 0}$ & $\mathbf{2 5 0}$ \\
\hline $\mathrm{NBTS}$ & 77.10 & 70.74 & 67.51 & 62.5 & 56.25 \\
\hline$\left[\mathrm{Cu}(\mathrm{NBTS})_{2}\right] \mathrm{Cl}_{2}$ & 95.42 & 81.52 & 74.69 & 72.48 & 59.19 \\
\hline$\left[\mathrm{Co}(\mathrm{NBTS})_{2}\right] \mathrm{Cl}_{2}$ & 55.41 & 35.61 & 30.58 & 26.55 & 24.91 \\
\hline$\left[\mathrm{Ni}(\mathrm{NBTS})_{2}\right] \mathrm{Cl}_{2}$ & 55.48 & 47.11 & 39.41 & 31.81 & 25.88 \\
\hline Standard & 81.16 & 86.36 & 91.56 & 93.18 & 96.36 \\
\hline
\end{tabular}




\section{DPPH assay}

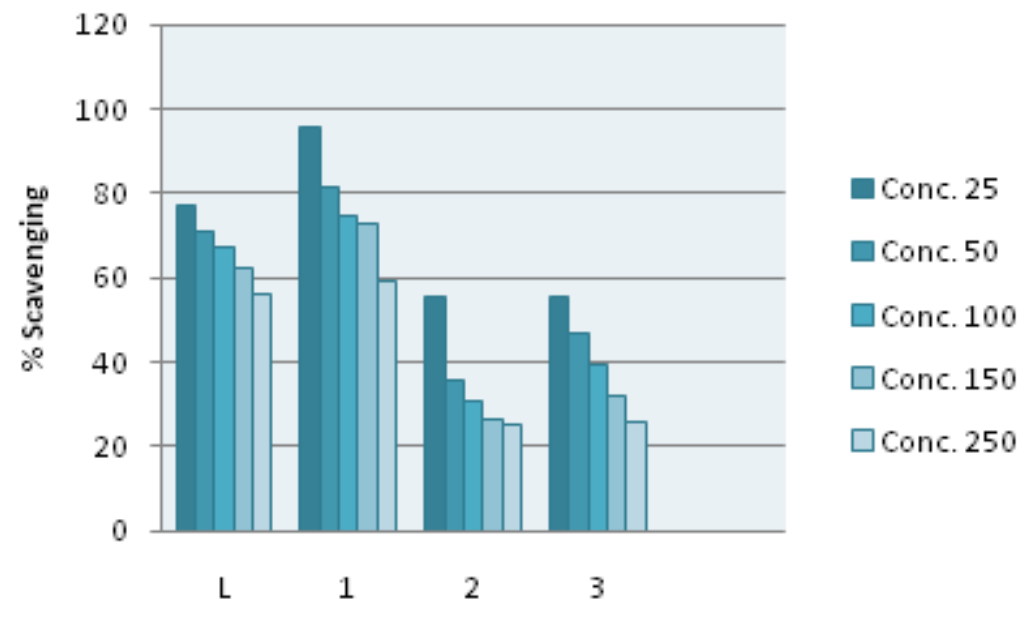

Fig7. DPPH method of radical scavenging activity

\subsection{Antibacterial Activity}

The antibacterial efficacy of the compounds was tested against two Gram positive bacteria namely Staphylococcus aureus and Bacillus cereus and Gram negative bacteria namely Pseudomonas aeruginosaand Escherichia coliby agar well diffusion method. ${ }^{[44]}$ Twenty four old Muller-Hinton broth cultures of test bacteria were swabbed on sterile Muller-Hinton agar plates using sterile cotton swab followed by punching wells of $6 \mathrm{~mm}$ with the help of sterile cork borer. The standard drug (Chloramphenicol, $1 \mathrm{mg} / \mathrm{ml}$ of sterile distilled water), compounds (2-4) $(20 \mathrm{mg} / \mathrm{ml}$ in $10 \%$ DMSO) and control (10\% DMSO) were added to respectively labeled wells. The plates are allowed to stand for 30 min. and were incubated at $37^{\circ} \mathrm{C}$ for $24 \mathrm{hrs}$ in upright position and the zone of inhibition was recorded. ${ }^{[45]}$

The result of antibacterial activity of the complexesis shown in Table5.In the antibacterial study, the compounds have shown inhibition of test bacteria. Among the compounds, marked inhibition of test bacteria was observed in compound $\left[\mathrm{Cu}(\mathrm{NBTS})_{2}\right] \mathrm{Cl}_{2}$ as compared with standard drugs.

Table5. Antibacterial activity of NBTS and its metal complexes

\begin{tabular}{|c|c|c|c|c|c|}
\hline \multirow{2}{*}{ Compound } & \multicolumn{5}{|c|}{ Zone of inhibition in (cm) } \\
\cline { 2 - 6 } & B. cereus & S. aureus & P. aeruginosa & K. pneumonia & E. coli \\
\hline NBTS & 1.0 & 1.5 & 1.3 & 1.4 & 1.6 \\
\hline$\left[\mathrm{Cu}(\mathrm{NBTS})_{2}\right] \mathrm{Cl}_{2}$ & 2.5 & 1.9 & 1.8 & 2.2 & 2.4 \\
\hline$\left[\mathrm{Co}(\mathrm{NBTS})_{2}\right] \mathrm{Cl}_{2}$ & 1.1 & 1.3 & 1.5 & 1.4 & 1.2 \\
\hline$\left[\mathrm{Ni}(\mathrm{NBTS})_{2}\right] \mathrm{Cl}_{2}$ & 1.5 & 1.2 & 1.7 & 1.6 & 1.4 \\
\hline Control & 0 & 0 & 0 & 0 & 0 \\
\hline Standard & 2.8 & 2.7 & 3.1 & 2.8 & 2.9 \\
\hline
\end{tabular}

\section{Conclusions}

In the present work, we successfully designed and developed a 5-methoxy-5,6-bis(3-nitrophenyl)-4,5dihydro-1,2,4-triazine-3(2H)-thione (NBTS) and its metal complexes. The ligand and their complexes have been characterized by various physicochemical techniques. The spectral data show that the complexes having octahedral geometry. The TGA/DTA data indicate stepwise degradation and from this, the kinetic parameters are evaluated. The obtained results are in good agreement with the proposed structure. The IR spectra indicate that the ligand coordinated through two donar sulphur atoms. The antibacterial and antioxidant activity results reveal that the $\left[\mathrm{Cu}(\mathrm{NBTS})_{2}\right] \mathrm{Cl}_{2}$ complex exhibited good activity compared to the uncoordinated ligand and the other two complexes in Fig.7.

\section{ACKNOWLEDGEMENT}

We greatly acknowledge the University Grant commission New Delhi for financial supportfor providing research facilities as well as the Principal, Sahyadri Science College, Shimoga, Kuvempu University and SAIF for spectral analysis, Cochin. 


\section{REFERENCES}

[1] Colak A.T., Tu"mer M., Serin S., Nickel ion as a template in the synthesis of macro cyclic imineoxime complexes from carbonyl compounds and o-phenylenediamine, Transition Met Chem, 25,200-204 (2000).

[2] Niasari MS., Najafian H., One-Pot Template Synthesis and Properties of Ni (II) Complexes of 16-Membered Hexaaza Macro cycles, Polyhedron, 22, 2633-2638 (2003).

[3] Prasad R.N., Mathur M., CrIII, FeIII, CoII, NiII, CuII and ZnII complexes of 26-and 28membered tetraaza macro cycles, Journal of the Indian Chemical Society, 83(12) ,1208-1213 (2006).

[4] Shakir M., Chingsubam P., Chisti H.T.N., Azim, Begum N., Synthesis and Physico-chemical studies on 20-membered decaaza macro cyclic complexes of $\mathrm{Mn}(\mathrm{II}), \mathrm{Fe}(\mathrm{II}), \mathrm{Co}(\mathrm{II}), \mathrm{Ni}(\mathrm{II}), \mathrm{Cu}$ (II) and $\mathrm{Zn}$ (II) derived from 2,6-diacetylpyridine dihydrazone, Indian J. Chem., 43A, 556-561 (2004).

[5] Chandra S., Gupta R., Gupta N., Bawa S. S., Biologically Relevant Macro cyclic Complexes of Copper Spectral, Magnetic, Thermal and Antibacterial Approach, Transition Met. Chem., 31, 147-152 (2006).

[6] Singh R.V., Chaudhary A., Biologically relevant tetraaza macro cyclic complexes of manganese: synthetic, spectral, antimicrobial, antifertility and antiinflammatory approach, J. Inorg. Biochem, 98, 1712-1721 (2004).

[7] Haiduc I., Silvestru A., Metal compounds in cancer chemotherapy, Coord. Chem.Rev, 99, 253296 (1990).

[8] Arquero A.C.M., Martinez R.M., Mendiola M.A., Rriz A.V., Selective access to new semicarbazones and thiosemicarbazones derived from benzil. Study of their conversion reactions, Tetrahedron, 54, 11271 (1998).

[9] French F.A., Blanz E.J.J., The carcinostatic activity of alpha-(N) heterocyclic carboxaldehydethiosemicarbazones. I. Isoquinoline-1-carboxaldehyde thiosemicarbazone, Cancer Res, 25(9), 1454 (1965).

[10] Kurup M.R.P, Joseph M., Transition Metal Complexes of Furan-2-aldehyde Thiosemicarbazone, Synth React Inorg. Met. Org. Chem, 33, 1275-1287 (2003).

[11] West D.X., Liberla A.E., Pandhye S.B., Chikate R.C., Sonawane P.B., Kumbhar S., Yerande R.G., Thiosemicarbazone complexes of copper(II): structural and biological studies. Coord Chem.Rev, 65,123 (1993).

[12] Shewach, D.S., Kuchta R. D. Introduction to Cancer Chemothera-peutics, Chem. Rev, 109(7), 2859-2861 (2009).

[13] Kelland L.R., Barnard F.J., Evans I.G., Murrer B.A., Theob-ald B.R.C., Wyer S.B., Goddard P.M., Jones M., Valenti M., Synthesis and in vitro and in vivo antitumor activity of a series of trans platinum antitumor complexes. J. Med. Chem., 38(16), 3016-3024 (1995).

[14] Abele E., Lukevics E., Synthesis of sterically hindered heteroaromatic ketones under phasetransfer and metal-complex catalysis conditions (Review). Chemistry of Heterocyclic Compounds, 37(1), 5-14 (2001).

[15] Vasoya S.L., Paghdar D.J., Chovatia P.T., Joshi H.S., Synthesis of some New Thiosemicarbazide and 1,3,4-Thiadiazole Heterocycles Bearing Benzo[b]Thiophene Nucleus as a Potent Antitubercular and Antimicrobial Agents, Journal of Sciences Islamic Republic of Iran. 16(1), 33-36 (2005).

[16] Vogel A.I.A., Text book of Quantitative Organic Analysis, 3rd edition ELBS Longmans Green and.Ltd, 436 (1962).

[17] Aranzazu B.M., Macrocyclization of cyclic thiosemicarbazones with mercury salts, Tetrahedron, 58(8), 1525-1531 (2002).

[18] Bindu P., Kurup M.R.P., E.s.r. and electrochemical studies of four and five-coordinate copper (II) complexes containing mixed ligands, Transition Met. Chem., 22(6), 578-582 (1997). 
[19] Subbaraj P., Ramu A., Raman N., Mixed Ligand Complexes Containing (2-Hydroxy- 4 Methoxyphenyl) (Phenyl) Methanone and 2-Aminophenol: Synthesis and DNA Cleavage, International Journal of Emerging Science and Engineering, 7, 6378 (2013).

[20] Garg BS,Kurup MRP, Jain SK,Bhoon YK.Manganese (II) complexes of substituted thio-and selenosemicarbazones of 2-acetylpyridine: E.s.r., magnetic and electronic spectral studies, Transition Met. Chem., 13, 92-95 (1988).

[21] Zhang Z.L., Wang Y., Synthesis and Characterization of N-benzoyl-N'-carboxyalkyl Substituted Thiourea Derivatives, Phosphorus, Sulfur Silicon Relat. Elem. 178,293-297 (2003).

[22] Mayer R., Janssen M.J., Organosulfur Chemistry. Wiley-Interscience, New York, p. 219, 9 (1967).

[23] El-Saied F.A., Donia A.M., Hamza S.M., Kinetics of oxidation of $\mathrm{Cr}_{3} \mathrm{~B}_{4}$ cermets cemented by different metallic binders: Part 2. Using cobalt and nickel as binders.Thermochim. Acta, 189,297-311 (1991).

[24] Jones L.H., Systematics in the vibrational spectra of uranyl complexes, Spectrochim. Acta, 10, 395-403 (1958).

[25] Chikate R.C., Belapure A.R., Padhye S.B., West D.X., Transition metal quinonethiosemicarbazone complexes 1: Evaluation of EPR covalency parameters and redox properties of pseudo-square-planar copper (II)-naphthoquinonethiosemicarbazones, Polyhedron, 24,889899 (2005).

[26] El-Gammal O.A., Abu El-Reash G.M., El-Gamil M.M., Binuclear copper(II), cobalt(II) and Nickel(II) complexes of $\mathrm{N}^{1}$-ethyl- $\mathrm{N}^{2}$-(pyridin-2-yl) hydrazine-1,2-bis(carbothioamide): Structural, spectral, pH-metric and biological studies. J. Spectrochim. Acta, 96,444-455 (2012).

[27] Kumar R., Singh R., Chromium (III) Complexes with Different Chromospheres Macrocyclic Ligands: Synthesis and Spectroscopic Studies, Turk. J. Chem, 30, 77-87 (2006).

[28] Hankare P.P., Naravane S.R., Bhuse V.M., Delekar S.D., Jagtap A H., Synthesis and characterization of $\mathrm{Mn}(\mathrm{II}), \mathrm{Co}(\mathrm{II}), \mathrm{Ni}(\mathrm{II}), \mathrm{Cu}(\mathrm{II})$ and $\mathrm{Zn}$ (II) azocoumarin complexes, Indian $\mathrm{J}$. Chem., 43A, 1464-1467 (2004).

[29] Rao T.R., Archana P., Synthesis and spectral studies on 3d metal complexes of mesogenicschiff base ligands: Complexes of N- (4-Butylphenyl) salicylaldimine, Synth React Inorg Met-Org Chem., 35,299-304 (2005).

[30] Singh D.P., Kumar R., Malik V.,Tyagi P., Synthesis and characterization of complexes of $\mathrm{Co}(\mathrm{II}), \mathrm{Ni}(\mathrm{II}), \mathrm{Cu}(\mathrm{II}), \mathrm{Zn}(\mathrm{II})$, and $\mathrm{Cd}(\mathrm{II})$ with macrocycle 3,4,11,12-tetraoxo 1,2,5,6,9,10,13,14octaazacyclo-hexadeca-6,8,14,16-tetraene and their biological screening, Trans. Met. Chem. 32, 1051 (2007).

[31] Lever A.B.P., Inorganic Electronic Spectroscopy, second ed., Elsevier Amesterdam, (1984).

[32] El-Metwally N.M., El-Shazly R.M.,Gabr I.M., El-Asmy A.A., Physical and spectroscopic studies on novel vanadyl complexes of some substituted thiosemicarbazides, Spectrochem.Acta, 61,1113- 1119 (2005).

[33] Abd El-Wahed M.G., Metwally S.M., El-Gamel M.M., Abd-el Haleem S.M., Thermodynamic and Electrical Properties of Aminophenol and Anthranilic Acid Complexes with Some Transition Metals, Bull.Korean Chem. Soc, 22.663- 668 (2001).

[34] Sulekh C., Smriti R., Sangeeta S., Synthesis and Spectroscopic Studies Of Cobalt (II) Complexes with nitrogen-Oxygen and Nitrogen Sulphur Donor Ligands, Journal of Pharmaceutical Sciences and Research, 5 (11), 472 (2014).

[35] Kong K., Zhang H.,Ruijun M.A., ChenY., Chu H., ZhaoY., Synthesis, characterization and enhanced luminescence of terbium complexes with 2-pyrazinecarboxylic acid and butanedioic acid by inert-fluorescent lanthanide ions, Journal of Rare Earth, 31,32-36 (2013).

[36] Mortimer R.G., Physical Chemistry A., Harcourt and Science Technology, Company, Academic Press, San Diego, (2000).

[37] Frost A.A., Pearson R.G., Kinetics and Mechanisms, Wiley, New York, (1961).

[38] Abdel-Nasser M.A., Alaghaz1, Rabie S., Farag., Mohammed A., Elnawawy., Ahmed D.A., Ekawy., Synthesis and Spectral Characterization Studies of New TrimethoprimDiphenylphosphate Metal Complexes, International Journal of Science and Research, 5,12201229 (2016). 
Synthesis, Characterization, Thermal Degradation Studies of Transition Metal Complexes of 5-Methoxy5,6-Bis(3-Nitrophenyl) - 4, 5-Dihydro-1, 2, 4- Triazine - 3 (2H) - Thione and Their Biological Activities

[39] Aliage C., Lissi E.A., Reaction of 2, 2'-azinobis (3-ethylbenzothiazoline-6-sulfonic acid (ABTS) derived radicals with hydro peroxides. Kinetics and mechanism, Int. J. Chem. Kinet, 30,565- 570 (1998).

[40] Miller N.J., Rice-Evans C.A., Factors influencing the antioxidant activity determined by the ABTS•+ radical cation assay, Free Radic Res, 26:195-199 (1997).

[41] El-Gazzar A.B.A., Youssef A.M.S., Youssef M.M., Abu-Hashem A.A., Badria,Eur F.A., Design and synthesis of azolopyrimidoquinolines, pyrimidoquinazolines as anti-oxidant, antiinflammatory and analgesic activitie, European Journal of Medicinal Chemistry, 44, 609-624 (2009).

[42] Aeschlach R., Loliger J., Scott C.B., Murcia A., Butler J., Halliwel B., Aruoma I.O., Antioxidant actions of thymol, carvacrol, 6-gingerol, zingerone and hydroxytyrosol, Food Chem. Toxicol, 32,31-36 (1994).

[43] Alagarsamy V., Meena S., Ramseshu V.K., Solomon R.V., Thirumurugan K., Dhanabal.K., Murugan M., Synthesis, analgesic, anti-inflammatory, ulcerogenic index and antibacterial activities of novel 2-methylthio-3-substituted-5,6,7,8-tetrahydrobenzo (b) thieno [2,3-d] pyrimidin-4(3H)-ones, Eur. J. Med. Chem., 41,1293-1300 (2006).

[44] El-Shafei A., Fadda A.A., Khalil A.M., Ameen T.A.E., Badria F.A., Synthesis, Antitumor Evaluation, Molecular Modeling and Quantitative Structure-Activity Relationship (QSAR) of some novel arylazopyrazolodiazine and Triazine Analogs, Bioorganic \& Medicinal Chemistry, 17, 5096-5105 (2009).

[45] Mohamed Mohamed Youssef, Mahmoud Ahmed Amin. Microwave Assisted Synthesis of Some New HeterocyclicSpiro-Derivatives with Potential Antimicrobial andAntioxidant Activity. Molecules, 15:8827-8840, (2010). 